\title{
Pengembangan Pembelajaran Pendidikan Agama Islam Melalui Pembelajaran Konstruktivistik Dan Sosiokultural
}

\author{
Aida Arini ${ }^{1}$, Halida Umami ${ }^{2}$ \\ ${ }^{1}$ Universitas Muhammadiyah Malang, ${ }^{2}$ Universitas Hasyim Asy'ari (UNHASY) Jombang \\ 12azhaapink@gmail.com, ${ }^{2}$ halidaumami@gmail.com
}

\begin{abstract}
Constructivistic learning is a learning that emphasizes the activity learners and relearning that has been previously possessed. As for the role of teachers in the learning process is as a facilitator who must support the learners in reconstruct the knowledge he has had then associated with new knowledge gained from educators during the process Learning. In sociocultural learning emphasizes more on the interaction between learners and others who will be associated with new knowledge built by educators in the learning process.
\end{abstract}

Keywords: Constructivism, Islamic Education, Sociocultural.

\begin{abstract}
Abstrak
Pembelajaran konstruktivistik merupakan pembelajaran yang menekankan keaktifan peserta didik serta membangun kembali pengetahuan yang telah ia miliki sebelumnya. Adapun peran guru dalam proses pembelajaran yakni, sebagai fasilitator yang harus mendukung peserta didik dalam mengkonstruk ulang pengetahuan yang telah ia miliki kemudian dikaitkan dengan pengetahuan baru yang diperoleh dari pendidik selama proses pembelajaran. dalam pembelajaran sosiokultural lebih menekankan kepada interaksi antara peserta didik dengan sesame yang akan dikaitkan dengan pengetahuan baru yang dibangun oleh pendidik dalam proses pembelajaran.
\end{abstract}

Keta Kunci: Kontruktifisme, Pendidikan Agama Islam, Sosiokultural

\section{Pendahuluan}

Peran guru sebagai pendidik sangat berpengaruh dalam mengoptimalkan kompetensi yang dimiliki oleh peserta didik sehingga mereka siap serta mampu berinteraksi dan beradaptasi dalam kehidupan nyata dengan baik. Langkah konkret yang harus dilakukan dalam suatu pembelajaran ialah menyusun kurikulum. Selanjutnya berdasarkan kurikulum yang telah ditentukan proses pembelajaran diharapkan berjalan dengan arah dan tujuan yang telah ditentukan. 
Tentunya dalam pencapaian tujuan pembelajaran harus didukung oleh peran guru secara maksimal. Guru harus mengetahui dan menerapkan langkah yang tepat dalam proses pembelajaran. Oleh karena itu untuk mewujudkan tujuan pembelajaran secara komprehensif guru harus mampu memahami konsep-konsep pembelajaran yang ada.

Dengan berkembangnya peradaban, manusia pun ikut terus berkembang, untuk memenuhi kebutuhan dan tuntutan masyarakat terhadap kompetensi yang dimiliki siswa maka, sudah tidak lagi diorientasikan hanya pada kompetensi kognitif. Namun, semua ranah kompetensi yang meliputi kompetensi afektif, psikomotorik, dan kognitif menjadi hal yang wajib dimiliki oleh peserta didik. Dengan adanya tuntutan yang sedemikian rupa tentu saja akan berdampak pada konsep pendidikan yang dilaksanakan oleh pendidik.

Paradigma pendidik harus mulai diubah dari paradigma pembelajaran yang berpusat pada guru ke arah pembelajaran yang berpusat pada siswa. Dari pembelajaran berbasis buku teks menuju pembelajaran berbasis konteks dan riset. Dengan adanya perubahan pandangan yang dimiliki pendidik diharapkan akan berimplikasi kepada pembelajaran yang akan dilakukan dalam kelas. Perubahan pandangan yang mendasari proses pembelajaran tentunya harus didukung oleh pemahaman guru (pendidik) terhadap konsep pembelajaran konstruktivisme.

Konsep pembelajaran konstruktivisme merupakan pembelajaran yang berpusat pada pemahaman. Bahwa proses belajar yang dilakukan oleh peserta didik merupakan proses konstruksi pengetahuan, pemahaman dan pengalaman yang dilakukan oleh peserta didik sebelum pendidik memberikan stimulus dalam proses pembelajaran dalam kelas. Pada proses pembelajaran ini, pendidik dituntut menjadi fasilitator yang baik, mampu menggali potensi peserta didik. Dalam hal ini maka diharapkan peserta didik mampu menemukan pengetahuan dan pengalaman yang dilakukan oleh peserta didik sendiri serta mengembangkan kemampuannya dan mengajukan pertanyaan dari hasil pengalamannya sendiri.

Namun, dalam teori sosiokultural meyakini bahwa perkembangan kognitif seseorang merupakan sebuah hasil dari interaksinya dengan lingkungan sekitar dan masyarakat. Dari interaksi dengan lingkungan dan masyarakat inilah seseorang mampu membentuk perkembangan kongnitifnya. Dari latar belakang yang dipaparkan oleh penulis maka tulisan ini akan berfokus pada teori konstruktivisme dan sosiokultural dalam pengembangan metode pembelajaran Pendidikan Agama Islam (PAI). 


\section{Metode}

Pendekatan kajian dalam tulisan ini adalah literatur atau penelitian kepustakaan (library research), artinya sebuah studi dengan mengkaji buku-buku atau sumber yang relevan dengan pokok permasalahan dan tujuan penelitian dalam tulisan ini. Semua sumber berasal dari bahan-bahan tertulis yang berkaitan dengan permasalahan penelitian.

\section{Temuan dan Diskusi}

Teori Konstruktivisme

Istilah konstruktivisme berasal dari kata kerja "to construct". Kata ini merupakan serapan dari bahasa latin "con struere" yang berarti menyusun atau membuat struktur. Konsep inti konstruktivisme dengan demikian adalah proses penstrukturan atau pengorganisasian. Secara istilah, konstruktivisme merupakan suatu teori belajar mengajar yang mengedepankan konstruksi (bentukan) pengetahuan yang berasal dari diri sendiri. ${ }^{1}$ Teori konstruktivisme, lahir dari adanya ketidakpuasan terhadap penemuan para ahli sebelumnya, yang menekankan bahwa belajar merupakan proses hubungan stimulusrespons-reinforcement. Teori ini menyatakan bahwa setiap individu mempunyai kemampuan mengarahkan diri (self-direction), dan pengendalian diri (self control) yang bersifat kognitif. ${ }^{2}$

Suparno berpendapat, bahwa dalam paham konstruktivisme pengetahuan adalah hasil dari konstruksi (bentukan) seseorang yang mengenal sesuatu (skemata), yang mana pengetahuan ini bukan hasil transfer dari seorang pendidik kepada orang lain karena setiap individu memiliki pengetahuan yang ia ketahuinya. ${ }^{3}$ Dalam konteks filsafat pendidikan, konstruktivisme ialah usaha untuk menata susunan hidup berbudayakan modern. Konstruktivisme merupakan landasan berpikir dan pembelajaran yang konstekstual dengan mengedepankan bahwa pengetahuan dibangun oleh individu secara perlahan, yang kemudian akan diperluas dengan batasan yang telah ditentukan dan tidak secara tiba-tiba muncul dari dalam diri peserta didik.

Adapun menurut Tran Vui, konstruktivisme ialah suatu teori belajar yang berlandaskan atas pengalaman sendiri. Sedangkan, teori konstruktivisme adalah sebuah teori yang memberikan kebebasan kepada setiap individu untuk mengembangkan

\footnotetext{
${ }^{1}$ Sukiman, “Teori Pembelajaran dalam Pandangan Konstruktivisme dan Pendidikan Islam,” Jurnal Kependidikan Islam 3, no.1 (2008), 59. 88.

2 Abuddin Nata, Perspektif Islam tentang Strategi Pembelajaran (Jakarta: Prenada Media, 2009),

${ }^{3}$ Paul Suparno, Filsafat Konstruktivisme dalam Pendidikan (Yogyakarta: Kanusius, 1997), 70. Indonesian Journal of Islamic Education Studies (IJIES)

Volume 2, Nomor 2, Desember 2019 
kemampuan dan pengetahuan yang telah dimilikinya. ${ }^{4}$ Dari pemaparan keterangan di atas, dapat diambil kesimpulan bahwa teori konstruktivisme merupakan teori yang memberikan kearifan dan kesempatan bagi peserta didik untuk menemukan pengetahuan, pengalaman dengan sendirinya agar mampu mengembangkan dirinya sesuai dengan kemampuan yang dimilikinya. Adapun motivasi untuk peserta didik bahwa belajar telah menjadi tanggung jawab dirinya sendiri dan guru sebagai fasilitator dalam pembelajaran.

Teori ini mempunya tujuan dan prinsip. Tujuan teori ini meliputi, keikutsertaan siswa dalam mengajukan pertanyaan serta mencari pertanyaan sendiri, membantu mengembangkan pengertian dan pemahaman konsep secara lengkap, dan membentuk kemampuan siswa menjadi seorang pemikir yang mandiri serta lebih menekankan kepada proses belajar. Adapun prinsip-prinsip konstruktivisme yang telah banyak digunakan dalam pembelajaran antara lain, peserta didik membangun pengetahuan secara aktif, proses belajar dipusatkan atau ditekankan kepada peserta didik, proses mengajar ialah proses membantu peserta didik, lebih menekankan pada proses belajar dari pada hasil akhir, kurikulum mengedepankan partisipasi peserta didik, dan peran pendidik adalah fasilitator. $^{5}$

\section{Konsep Konstruktivisme dalam Pembelajaran PAI}

Sigit berpendapat mengenai pembelajaran konstruktivisme yang menekankan bahwa cara membangun pengetahuan atau kemampuan baru membutuhkan proses konstruksi yang harus dibangun oleh peserta didik sendiri dari hasil pengetahuan dan pengalaman yang telah dimilikinya. ${ }^{6}$ Pembelajaran konstruktivisme merupakan pembelajaran yang cukup baik di mana peserta didik ikut serta dalam proses pembelajaran di kelas dan bukan hanya menerima pelajaran dari pendidik yang kemudian peserta didik menjadi pasif dalam proses pembelajaran seperti halnya dalam pembelajaran yang menganut teori behaviorisme.

Dalam teori ini peserta didik diharuskan menemukan sendiri dan kemudian mentransformasikan informasi yang telah kompleks, mengecek informasi baru dengan aturan lama yang kemudian akan direvisi jika aturan tersebut tidak sesuai lagi. Tugas siswa yang harus diperhatikan ialah memahami dan menerapkan pengetahuan, dengan

\footnotetext{
4 Muhammad Thobroni dan Arif Mustafa, Belajar \& Pembelajaran Pengembangan Wacana dan Praktik Pembelajaran dalam Pembangunan Nasional (Yogyakarta: AR-Ruzz Media, 2011), 108.

${ }^{5}$ Suparno, 73.

6 Sigit Mangun Wardoyo, Pembelajaran Konstruktivisme Teori dan Aplikasi Pembelajaran (Bandung: Alfabeta, 2013), 22.
} 
cara mencari masalah yang kemudian harus dipecahkan serta harus mencari segala sesuatu baru dari pengalaman yang akan membantu dirinya dalam mengembangkan kemampuan yang telah ia miliki.

Satu prinsip yang harus diperhatikan dalam teori ini ialah bahwa seorang pendidik dalam proses pembelajaran bukan hanya memberikan pengetahuan secara langsung kepada peserta didik, namun peserta didik sendirilah yang harus mencari, menemukan, dan kemudian memecahkan masalah yang telah ia temukan. Lantas tugas guru memberikan kesempatan kepada peserta didik untuk menemukan dan menerapkan ideide yang telah mereka dapatkan sehingga mereka sadar akan pentingya mengaplikasikan strategi belajar yang telah mereka susun dengan pengetahuan mereka sendiri. ${ }^{7}$

Pembelajaran konstruktivisme mempunyai beberapa strategi penerapan yaitu, pertama top-down processing. Dalam pembelajaran kontruktivisme, peserta didik belajar mulai dari masalah yang utuh kemudian harus dipecahkan sehingga mampu menghasilkan atau menemukan keterampilan yang dibutuhkan. Contohnya, peserta didik dianjurkan untuk membaca, kemudian ia akan belajar untuk mengeja kalimat yang akan dibaca tersebut.

Kedua, cooperative learning. Strategi yang diterapkan dalam proses belajar, yang mana peserta didik akan menyelesaikan pemecahan masalah setelah ia berdiskusi dengan teman atau kelompok. Strategi ini lebih menekankan lingkungan belajar dan dari lingkungan itulah peserta didik mampu mengeksplorasi, mengutarkan serta menantang pengetahuan yang telah ia miliki di depan kelompok belajar yang telah ditentukan oleh guru. Ketiga, generative learning. Strategi ini membantu peserta didik untuk mengintegrasikan materi dan pengetahuan baru secara aktif dalam proses pembelajaran. dengan teori ini mampu mengajarkan peserta dalam mmbuat pertanyaan serta kesimpulan dengan baik. ${ }^{8}$

Pembelajaran konstruksitivisme mencakup beberapa unsur penting yang mencakup pertama, memperhatikan dan memanfaatkan pengetahuan awal peserta didik. Kegiatan pembelajaran ditujukan kepada peserta didik agar mampu membangun atau mengonstruk ulang pengetahuan yang sudah ia miliki di awal dengan pengetahuan baru sehingga mampu mendorong siswa agar terjadi perubahan dengan memanfaatkan teknik yang telah ia miliki. Kedua, pengalaman belajar yang autentik dan bermakna.

\footnotetext{
7 Trianto, Mendesain Model Pembelajaran Inovatif-Progresif (Jakarta: Prenada, 2009), 28.

${ }^{8}$ Baharuddin dan Esa Nur Wahyuni, Teori Belajar dan Pembelajaran (Yogyakarta: Ar-Ruz Media, 2007), 128.
} 
Pembelajaran dirancang dengan kegiatan sedemikian rupa agar menjadi bermakna bagi siswa. Oleh karena itu minat, bakat, sikap, kebutuhan siswa menjadi pertimbangan penting dalam pembelajaran. Gagasan ini bisa dilihat dari usaha yang dilakukan oleh guru dalam mengaitkan pelajaran dengan kehidupan sehari-hari dan juga penerapan konsep.

Ketiga, Terbentuknya lingkungan sosial yang kondusif. Kegiatan pembelajaran menawarkan kesempatan penuh kepada peserta didik agar terus berinterkasi secara produktif antar siswa maupun guru. Dari hal inilah siswa mampu untuk bersosialisasi dengan lingkungan secara kondusif. Keempat, mendorong peserta didik agar lebih mandiri. Di kesempatan ini peserta didik harus mampu bertanggung jawab terhadap proses belajarnya. Sehingga mereka mendapatkan kesempatan untuk merefleksi dan menata kegiatan belajarnya. Kelima, usaha pengenalan tentang dunia ilmiah kepada peserta didik. Pada ilmu sains diharapkan bukan hanya mengajarkan tentang produk, konsep, prinsip serta teori, akan tetapi diharapkan mampu memberikan pelajaran sikap serta proses. Dengan ini maka diharapkan sains mampu mengenalkan kehidupan ilmuwan kepada peserta didik. ${ }^{9}$

Penerapan teori konstruktivis juga mempunyai beberapa kelemahan dan kelebihan. Kelebihannya yaitu peserta didik mampu untuk menyelesaikan masalah, merealisasikan ide serta membuat keputusan dalam proses pembelajaran, peserta didik menjadi lebih paham dan dapat mengaplikasikan langsung karena terlibat dalam proses pembelajaran, peserta didik akan mengingat lebih lama semua konsep pembelajaran karena ia terlibat langsung secara aktif, peserta didik akan lebih mampu bersosialisasi dengan lingkungan yang diperolehnya dari interaksi sesame teman dan guru, pemahaman peserta didik akan menjadi lebih akurat, yakin, dan mampu berinteraksi sehat sehingga menjadikan proses pembelajaran menyenangkan dan mampu membina pengetahuan baru. ${ }^{10}$ Sedangkan kelemahannya tampak dari beberapa hal, yaitu kurang mendukung peran guru sebagai pendidik, lebih sulit untuk dipahami karena cakupannya lebih luas.

Implikasi Teori konstruktivistik dalam pembelajaran berkaitan dengan rancangan pembelajaran, seperti yang diajukan oleh Tayler beberapa sarannya yakni, kesempatan bagi peserta didik untuk mengutarakan ide secara baik sesuai dengan bahasa sendiri, memberi kesempatan peserta didik untuk berfikir lebih kreatif dan imajinatif sesuai dengan pengalamannya, kesempatan peserta didik untuk mengaplikasikan ide baru,

9 Thobroni, 114.

10 Thobroni, 121. 
mendorong peserta didik dalam mengembangkan gagasan yang telah ia miliki, peserta didik mampu menciptakan lingkungan yang kondusif. ${ }^{11}$

Adapun tokoh kunci tepri ini adalah ahli psikologi Eropa Jean Piaget dan Lev Vygotsky serta ahli psikologi Amerika Jerome Bruner. Merekalah pakar paham konstruktivisme sekaligus pelopor konsep konstruktivisme. Jean Piaget ialah seorang ahli psikologi Swiss, yang paham sekali akan kemampuan anak berpikir dan berproses dalam perkembangan intelektual. Piaget menjelaskan rasa ingin tahu anak menjadi bawaan sejak lahir dan berkembang secara terus menerus sehingga mampu memahami dunia sekitarnya. Dalam dunia pendidikan ia mengatakan bahwa perkembangan intelektual manusia terjadi melalui tahapan yang sama dan secara berurutan. Ia pun menegaskan bahwa adanya pengetahuan tersebut berasal dari asimilasi dan akomodasi. Dengan penjelasan bahwa asimilasi merupakan hasil dari penyerapan informasi baru yang ada dalam pikiran. Sedangkan akomodasi yakni membangun kembali struktur pikiran dengan informasi baru sehingga mampu memberikan ruang pada informasi terbaru.

Vygotsky adalah ahli psikologi Rusia. Ia mengatakan bahwa ketika seseorang dihadapkan dengan pengalaman baru dan menantang mampu membantu perkembangan intelektualnya. Mereka akan berusaha untuk menghadapi masalah serta memecahkannya dengan kemampuan atau pengetahuan yang ia miliki. Demi mendapatkan pengetahuan baru maka ia mengaitkan pengetahuan yang telah ia miliki sejak awal kemudian ia bangun pengetahuan baru tersebut. Hanbury, mengemukakan aspek yang berkaitan dengan proses pembelajaran yaitu, pengkonstruksian siswa dalam mengintegrasikan ide yang telah mereka miliki, proses pembelajaran menjadi lebih bermakna, kesempatan bagi peserta didik dalam berdiskusi, bertukar pengalaman dan ilmu dengan temannya. Wheatley juga mengemukakan pentingnya melibatkan keaktifan peserta didik dalam proses pembelajaran sekaligus pengkonstrusian ilmu pengetahuan yang telah ia miliki dari sebelumnya melalui lingkungannya. Di sinilah akan memudahkan peserta didik dalam mempelajari sesuatu hal yang baru berdasarkan apa yang telah ia ketahui sebelumnya. ${ }^{12}$

\section{Teori Sosiokultural}

Pendekatan ini menyatakan bahwa manusia adalah makhluk sosial yang bermasyarakat dan berkebudayaan sehingga disebut sebagai "homo socius" dan "homo

11 Thobroni, 122.

12 Thobroni, 113. 
sapiens" dalam kehidupan bermasyarakat. Bila ditelaah lebih jauh bahwasanya manusia merupakan makhluk individu sekaligus makhluk sosial yang mana tidak terlepas dari bantuan orang lain dan membutuhkan orang lain dalam keberlangsungan hidup di dunia ini. Maka, dengan kesosialan manusia ia dapat bergabung di dalam kelompok kecil yang berada di sekelilingnya seperti, keluarga, kelompok yang lebih luas lagi dalam ranah kehidupan. ${ }^{13}$ Aplikasi teori sosiokultural sesuai dengan bunyi surat al-Maidah ayat 2 yang artinya "....dan tolong-menolonglah kamu dalam (mengerjakan) kebajikan dan takwa, dan jangan tolong-menolong dalam berbuat dosa dan pelanggaran. dan bertakwalah kamu kepada Allah, Sesungguhnya Allah Amat berat siksa-Nya."

Nama lain dari teori ini ialah teori konstruksi sosial yang menekankan pada intelegensi manusia muncul dari lingkungan, budaya dan juga masyarakat sekitarnya. Perolehan kongnitif individu pertama kali terjadi melalui interpersonal (interaksi dengan lingkungan sosial), intrapersonal (interaksi yang muncul dalam diri individu tersebut). ${ }^{14}$

Dalam kegiatan belajar dan mengajar perlu diadakan revolusi sosial budaya, sehingga sumber daya manusia dapat memenuhi tantangan global, yang berarti memiliki kemampuan yang dibutuhkan oleh dunia kerja. Untuk memenuhi kebutuhan masyarakat maka individu harus memiliki kemampuan untuk berpikir inovatif, kreatif, memecahkan masalah, menentukan keputusan dan juga mampu mengkolaborasikan serta pengelolaan diri. $^{15}$

\section{Pembelajaran PAI dengan Teori Sosiokultural}

Apabila teori konstruktivisme ala Piaget menyatakan bahwa suatu proses pembelajaran mengacu pada kemampuan peserta didik dalam mencari pengetahuan dan pengalaman secara individu atau dapat dikatakan teori konstruktivisme lebih menekankan pada self discovery learning. Berbeda dengan konstruktivisme sosial yang dikembangkan oleh Vygotsky yang mana lebih menekankan pada assited discovery learning yang berarti bahwa belajar dari anak-anak dilakukan dengan cara interaksi dengan lingkungan sosial maupu fisik. Menurut Vigotsky, teori sosiokultural ialah proses pembelajaran yang mengonstruksi suatu konsep dengan memperhatikan lingkungan sosial. ${ }^{16}$

\footnotetext{
13 Thobroni, 210

${ }^{14}$ Sri Wulandari, "Teori Belajar Konstruktivis Piaget dan Vygotsky," Indonesian Digital Jurnal of Education 2, no.3 (2015), 194.

${ }^{15}$ Moh.Yamin, Teori dan Metode Pembelajaran (Malang: Madani, 2015), 62.

16 Lokita Purnamika Utami, "Teori Konstruktivisme dan Teori Sosiokultural Aplikasi dalam pengajaran Bahasa Inggris," Jurnal PRASI 11, no. 01 (2016), 8.
} 
Dalam kaitannya dengan manusia sebagai makhluk individu sekaligus makhluk sosial jika diamati dari proses pembelajaran. Pendekatan ini sangat efektif jika diterapkan dalam membentuk sifat serta kepribadian siswa di mana kebersamaan siswa dengan lingkungan serta teman sebayanya di sekolah maupun luar sekolah menjadi salah satu cara dalam pembentukan sifat tersebut. Demikian pola ini diterapkan pada aspek pembentukan tingkah laku di mana seorang guru harus mampu menstimulus respon siswa dengan mengadakan kegiatan yang bernuansa kebersamaan dalam lingkungan sekolah ataupun luar sekolah. ${ }^{17}$

Vygotsky berpendapat bahwa proses pembelajaran pada anak terjadi ketika ia menyelesaikan tugas yang belum dipelajari. Tetapi tugas itu menjadi tanggung jawab mereka yang disebut dengan zone of proximal development, yaitu meningkatnya sedikit perkembangan di atas daerah perkembangan seseorang saat ini. Ia menyakini bahwa fungsi mental yang tinggi adalah hasil dari adanya interaksi antar sesama. Keberhasilan peserta didik dalam mengolah serta mengaitkan pengetahuan lama dan baru bergantung pada interaksi sosial peserta didik tersebut. Apabila terjadi interaksi sosial antar individu dengan lingkungannya baik maka, hal ini dapat dijadikan sebagai sarana dalam mewujudkan kegiatan belajar kondusif dalam diri peserta didik. ${ }^{18}$

Adapun satu ide yang dipaparkan oleh Vygostky adalah scaffolding yaitu memberikan bantuan kepada anak di awal perkembangannya kemudian memberikan kesempatan bagi anak untuk menyelesaikan tugasnya sesuai dengan tanggung jawab yang harus mereka selesaikan. Hasil penafsiran mengenai ide Vygostky ialah peserta didik harus diberikan tugas-tugas yang berat, kompleks, dan realistik kemudian diberikan bantuan secukupnya demi menyelesaikan tugas dengan sebaik mungkin. ${ }^{19}$ Dalam proses pembelajaran dengan teori ini membutuhkan scaffolder (orang/organisme yang mampu mendukung dalam proses pembelajaran). Scaffolder bukan hanya seorang guru atau orang dewasa sebagai pendukung dalam proses pembelajaran namun, organisme lain yang mampu melakukan interaksi sosial dengan peserta didik memiliki potensi pendukung dalam proses pembelajaran. ${ }^{20}$

Kelebihan teori ini mencakup beberapa hal, yaitu kesempatan bagi anak dalam mengembangkan zona perkembangan potensi dengan cara belajar serta berkembang,

${ }^{17}$ Armai Arief, Pengantar Ilmu dan Metodologi Pendidikan Islam (Jakarta: Ciputat Press, 2002), 104.

\footnotetext{
${ }^{18}$ Wardoyo, 32.

${ }^{19}$ Trianto, 39.
}

${ }^{20}$ Wardoyo, 33. 
adanya keterkaitan antara pembelajaran pada tingkat perkembangan potensial daripada tingkat aktualnya, untuk meningkatkan kemampuan intermental dan intramental maka, pembelajaran lebih diarahkan pada penggunaan strategi, kesempatan bagi peserta didik untuk mengintegrasikan pengetahuan deklaratif dengan pengetahuan procedural yang dapat dilakukan untuk menyelesaikan permasalahan yang ada, proses belajar dan pembelajaran bukan bersifat transferal namun, merujuk kepada mengembangkan pengetahuan secara bersamaan antara semua pihak yang terlibat didalamnya. Sedangkan kekurangannya adalah keterbatasan pada perilaku yang tampak saja, sehingga proses belajar yang belum kelihatan seperti, pemecahan masalah, kemampuan berpikir sulit untuk diamati secara langsung.

\section{Kesimpulan}

Proses pembelajaran dengan menggunakan teori konstruktivisme lebih menekankan pada keaktifan peserta didik dan membangun kembali pengetahuan yang telah ia miliki sebelumnya. Peran guru sebagai fasilitator harus mampu mendukung peserta didik dalam mengonstruksi ulang pengetahuan yang ia miliki sebelumnya kemudian dikaitkan dengan pengetahuan baru yang diperoleh dari pendidik selama proses pembelajaran. Ada tiga strategi belajar yang dikemukakan dalam teori konstruktivisme ialah, top down learning, cooperative learning dan generative learning.

Sedangkan teori sosiokultural ialah bahwa manusia adalah makhluk sosial yang bermasyarakat dan berkebudayaan sehingga disebut sebagai "homo soscius" dan "homo sapiens" dalam kehidupan bermasyarakat. Proses pembelajaran pada anak terjadi karena adanya interaksi antara peserta didik dengan sesama yang kemudian dikaitkan dengan pengetahuan baru yang dibangun oleh pendidik dalam proses pembelajaran. Interaksi inilah yang menjadi suatu penekanan pada suatu pembelajaran sehingga mampu mencapai tujuan yang telah ditetapkan.

\section{Daftar Rujukan}

Arief, Armai. Pengantar Ilmu dan Metodologi Pendidikan Islam. Jakarta: Ciputat Press, 2002.

Baharuddin dan Esa Nur Wahyuni Teori Belajar dan Pembelajaran. Yogyakarta: Ar-Ruz Media, 2007.

Nata, Abuddin. Perspektif Islam tentang Strategi Pembelajaran. Jakarta: Prenada Media, 2009. 
Sukiman. "Teori Pembelajaran dalam Pandangan Konstruktivisme dan Pendidikan Islam,” Jurnal Kependidikan Islam.3, no.1 (2008).

Suparno, Paul. Filsafat Konstruktivisme dalam Pendidikan. Yogyakarta: Kanusius, 1997.

Thobroni, Muhammad dan Arif Mustafa. Belajar \& Pembelajaran Pengembangan Wacana dan Praktik Pembelajaran dalam Pembangunan Nasional. Yogyakarta: AR-Ruzz Media, 2011.

Trianto. Mendesain Model Pembelajaran Inovatif-Progresif. Jakarta: Prenada, 2009.

Utami, Lokita Purnamika. "Teori Konstruktivisme dan Teori Sosiokultural Aplikasi dalam pengajaran Bahasa Inggris," Jurnal PRASI 11, no. 01 (2016).

Wardoyo, Sigit Mangun. Pembelajaran Konstruktivisme Teori dan Aplikasi Pembelajaran. Bandung: Alfabeta, 2013.

Wulandari, Sri. “Teori Belajar Konstruktivis Piaget dan Vygotsky," Indonesian Digital Jurnal of Education 2, no.3 (2015).

Yamin, Moh. Teori dan Metode Pembelajaran. Malang: Madani, 2015. 